\title{
ABOUT THE ADVANTAGES OF PUBLIC-PRIVATE PARTNERSHIPS AND ITS ORGANIZATIONAL FORMS
}

\author{
Popa Florina \\ Institutul de Economie Naţională, Academia Română \\ (Institute of National Economy, Romanian Academy) \\ florinapopa2007@gmail.com
}

\begin{abstract}
The advantages and disadvantages provided by joining in public-private partnership reveal the challenges the economies are constrained to, pursuant to the impact of PPP on certain economic processes. There are identified forms of public-private partnership, which, in their development, are based on a number of factors: the actors involved, the origin of the financial resources, the duration of the contract, the existing traditions, types of agreement in relation to the way of sharing responsibilities and risks between public and private actors. The paper reveals studies achieved on the elements of public-private partnership, advantages, disadvantages they highlight, the forms of partnership grouped in relation to different factors, the stages pursued in the initiation of public-private partnership projects.
\end{abstract}

\section{Keywords}

financial resources; agreements; projects; forms; partnership

\section{JEL Classification}

$\mathrm{H} 41 ; \mathrm{H} 42 ; \mathrm{H} 44$

\section{Introduction}

Studies and opinions concerning Public-Private Partnership are often met in proffesional economic, financial, judicial publications, used in marketing, in product and service supply, collaboration between the two sectors (public and, respectively, private,) being a contemporary chapter of interest of administrative actuality.

The problems faced by governments in their actions aimed at achieving a high efficiency in public works development such as insufficiency of governmental financial resources, have led to the initiation of new forms of institutional cooperation, generic called Public-Private Partnership (Wettenhall, 2003; Boase, 2000; Osborne, 2000).

Although the notion of Public-Private Partnership emerged in the 70s of the last century, on the background of the New Public Management procedures getting into public administration, the collaboration between the public and private sector dates back to the ancient times, in the course of history, undergoing transformations and evolving until the modern age. The cooperation with the private sector, by the privatization or outsourcing of public service delivery has led, over time, to a

\footnotetext{
$\square$ Acknowledgement:The study is a part of the research paper of the Institute of National Economy, Romanian Academy - "Rolul statului și parteneriatul public-privat (1918-2018)"- achieved in 2017, by a team of researchers - Dr. Cornel Ionescu (coordinator), Florina Popa;
} 
diminution in the role of the state and an increase in the performance of the public sector in public activities development (Savas, 1982).

\section{Advantages, disadvantages of Public-Private Partnership}

In this form of cooperation, the partners voluntarily commit themselves to a common goal achievement and, to this end, mobilize the necessary resources, the costs, risks, responsibility and profit allocating proportional to the contributions of the parties. Thus, the partnership is an expression of the participants' awareness of the advantages that the endeavour of such cooperation represent them, comparatively to the individual option.

The impact of PPP on some economic processes can lead to varied effects, both in terms of the advantages and disadvantages they develop.

\subsection{Advantages}

Among the advantages of partnerships practice, can be considered:

- can help to improvement of the operation form of state-owned enterprises, by giving the service delivery, implicitly carrying out some investments, to private entrepreneurs; without being the only provider, the public sector retains the role of decisions making on the chosen objectives and overseeing compliance with standards in the public interest;

- supporting public investments, the partnership mechanism allows the possibility for the development of infrastructure programs and, at the same time, for governmental resources orientation to support other economic and social sectors, avoiding taking or increasing public loans;

- there is a transfer of the project operational and execution risk from the public sector to the private sector, the latter having an advanced experience and technology of performance, which favours the increase in the pace of project implementation.

- it is created the possibility of introducing competitive principles into traditional activities of the public sector, which leads to an increase in service quality, encouragement of innovation, reduction of costs. Thus, the elements of PPP policy favour the private sector managerial principles getting in the economic concepts of the public sector, respectively, the implementation of the New Public Management;

- there are created the possibilities for the supplier, to ensure the performances, according to the contract's standards, these being a condition to accomplish payment of the services;

- there is a prospect of cost savings achievement in the implementation of a project through PPP, of a quality comparable to that of the traditional executions, or of a higher quality project, under the same level of expenditure;

- the mobilization and sharing of participants' resources, exchange of experience and the mutual support through implementation of the knowledge they hold is the stake in achieving the objectives pursued by the participants, their optimum being conditioned by the contribution of each of the associated partners.

\subsection{Disadvantages}

Performing some works in PPP can also lead to disadvantages such as: 
- engaging in some long-term contracts under a technology of execution, at that time, removes the supplier's constraint to adapt to new technologies (which involve additional costs associated with), to increase competitiveness;

- the PPP transaction costs (related to contract bidding, negotiation and administration) may be higher than those associated with traditional government purchases;

- the possibility of certain difficulties occurrence in the administration of the contracts, caused by a parties' faulty cooperation, the elements of difficulty may also be determined by the involvement of several actors, in the contract; the situation involves the need to manage possible conflicts of interest among the participants, through dialogue and negotiations which lead to their overcoming;

- obtaining the estimated profit, from the achievement of the project varies in relation to the volume of the assumed risks, the complexity of the project, the competitiveness of the developers;

- the government may encounter difficulties in assessing proposed costs for the cases where the private entity has a share of knowledge and experience in project implementation.

Reducing the probable disadvantages encountered in PPP works achievement can be favored by taking into account actions such as:

- the transfer of risk to the most qualified part in the achievement of the project, in order to optimize the results of the cooperation;

- close monitoring of the performance of the contract, of the quality and estimated performance;

- ensuring a satisfactory number of bidders, which will facilitate the introduction of competition, but will ensure the possibility of control on the quality of the offers.

\section{Forms of public-private partnership}

PPP is based on a contract between the public and private sector through which the private sector contributes with financial resources and projects, and the public sector is responsible for delivering services to the population, respecting the needs of individuals and contributing to the standard of living raise. (UNECE, 2008)

* Among the first forms of Public-Private Partnership are the mixed ones, which have varied over time, in relation to the actors involved, the origin of the financial resources, the duration of the contract, existing traditions in different countries, from which can be mentioned (Wettenhal, 2003):

$\Rightarrow \quad$ Mixed enterprises, existent in many countries where the structure and form of activities development were considered mixed, by the scientific literature. For example, the state-owned company, Singapore Airlines, which, although sold shares for capital growth, has maintained its status of state-owned company (Thynne and Ariff, 1987); Singapore Telecommunications Ltd (SingTel), where the government owns the majority of the shares, bought, entirely, the enterprise Australian Telecom Optus. (McDoanld, 2001).

$\Rightarrow \quad$ Outsourcing - agreements by which the public authority requests, by contract, to a private company, to carry out some activities, which remain the property of the public sector, pursuing to merge the public interests with the private ones. (Callender and Johnston, 1998). 
$\Rightarrow \quad$ The subsidy, controlled competition, regulation etc. - a related form that reveals aspects of the Public-Private Partnership; is manifested by granting subsidies from government to private companies in order to achieve objectives difficult to be met by the state.

* Although there are a variety of forms of Public-Private Partnership agreed between the government and various entities that cover different market areas, the scientific literature groups them into two broad categories:

$\Rightarrow \quad$ Institutionalized PPPs refer to a joint entity setting up - joint ventures which belong to public partner and to the private one, against providing a work or service for the benefit of the public.

The ways in which an institutionalized PPP can come into existence could be:

- creation of a new entity by the public and private actor;

- the private actor buys and holds shares in a public company, exploiting the service, and the public sector keeps the control of the company, through shares.

$\Rightarrow \quad$ Contractual PPPs are different forms of agreements that express contractual relationships between the public and private partner and the delegation of tasks to the private partner.

The two categories depend on country-specific implementation modalities and are regulated at European level.

* In relation to the forms of sharing responsibilities and risks between public and private actors, the models of contracts and, adequate, of Public-Private Partnerships, are presented as follows:

$\Rightarrow \quad$ Buy-Build-Operate (BBO) - contract through which the transfer of a public utility to a private or public entity is achieved through the sale, for the modernization and operation of the infrastructure over a specific period of time, on advantageous terms (The National Council for Public-Private Partnership; UNECE, 2008).

$\Rightarrow \quad$ Build-Own-Operate (BOO) - financing, construction, property and the operation of a utility come to the private sector, forever, without the public authority having to buy the public utility (The National Council for Public-Private Partnership; UNECE, 2008).

$\Rightarrow \quad$ Build-Own-Operate-Transfer (BOOT) - financing, designing, construction and operation a utility come to the private partner who will charge taxes for them, for a specified period. At the end of the period the property is transferred to the public sector (UNECE, 2008).

$\Rightarrow \quad$ Build-Operate-Transfer (BOT) - under a long-term concession contract, designing, financing, construction of a new utility come to the private partner who exploits it during the concession period (UNECE, 2008).

$\Rightarrow \quad$ Build-Lease-Operate-Transfer (BLOT) - financing, designing, construction and operation of a rented equipment and charging taxes of user during the lease contract period come to a private partner, through franchise (UNECE, 2008).

$\Rightarrow \quad$ Design-Build-Finance-Operate (DBFO) - through a long-term lease contract, designing, financing, construction of a new building and its exploitation during the lease period come to the private sector (UNECE, 2008).

$\Rightarrow \quad$ Operation License - it comes to a private partner, usually, for a specified period (UNECE, 2008). 
* Different from these classifications, also it can be mentioned other categories of PPP, in relation to some criteria (McQuaid, 2000):

a) In relation to the pursued objective - exogenous or endogenous, strategic or program or project-oriented partnerships.

- exogenous when it pursues to attract additional external resources or endogenous when it aims to maximize the efficiency of internal resources use.

- strategic or program or project-oriented: they pursue major goals of the organization by developing of a spread strategy for a particular area, or are geared towards specific long-term projects/programs. From the perspective of the area of activities pursued, the strategic partnerships can target a narrow or a wider area of activities.

b) In relation to the geographical area, it can identify:

- PPP targeted at certain categories of customers, from small disadvantaged urban areas or from larger areas;

- PPP oriented towards policies at national, regional or local level, such as those related to social exclusion, discrimination or urban regeneration.

c) In relation to the mobilization relationships between actors, within partnerships it can identify:

- Top-down, the initiative is taken by a high-level authority such as the central government;

- Bottom-up, the initiative is taken by local communities through strategies that rely on the local level existing resources. (Bailey, 1994; Friedmann and Weaver 1979).

\section{Conclusions}

Over time, there has been an increase in interest in partnerships as well as in the experience gained in their development, against a background of the emphasis of the privatization process, which has become almost dominant. Maintaining, in partnership, both parties, keeping the values of partnership and risk-taking can ensure a sustainable character for partnership.

The reason for partnership setting up, by appealing to the private sector, is largely due to the insufficiency of budgetary resources and technologies needed at the public sector level, in the achievement of public works and delivery of public services.

Through PPP, the public sector aims to attract additional financial resources needed to finance large infrastructure projects for which the funds collected from taxes and tax rates are not enough. The resources come from both the state budget and the private sector but also from the service users (partially or entirely), thus, increasing the safety of finalizing the projects at the scheduled time, avoiding the situation of spending overcome by the public sector, by setting up a payment scheme before the begining of construction.

By way of action, PPPs can determine advantages or disadvantages that generate a series of challenges, through the impact they have on the economic processes.

The forms of partnership have evolved over time, bearing changes in relation to the degree of involvement of the public and private sector, responsibilities and risks sharing between the two parties, the financial resources allocated, the objectives pursued, the historical period in which they have developed and the existing traditions. 


\section{References}

Bailey, N. (1994), Towards a research agenda for public-private partnerships in the 1990's, Local Economy: The Journal of the Local Economy Policy Unit, Vol. 8, Issue 4, 292-306.

Bailey, N., Barker, A., MacDonald, K. (1995), Partnership Agencies in British Urban Policy, London, UCL Press.

Belhocine, N., Facal, J., Mazouz, B. (2005), Les partenariats public-privé: Une forme de coordination de l'intervention publique à maîtriser par les gestionnaires d'aujourd'hui, Télescope, L'observatoire de l'administration publique, Revue d'analyse comparée en administration publique, Vol. 12, No. 1, available at http://cerberus.enap.ca/Telescope/docs/Index/Vol_12 no_1/Telv12n1_belhocin e facal mazouz.pdf.

Boase, J. P. (2000), Beyond Government? The Appeal of Public-Private Partnerships, Canadian Public Administration, Vol. 43, Issue 1, 75-92.

Callender, G., Johnston, J. (1998), Contracting Between Governments and the Private Sector: Private Haven or Public Risk?, pp. 23-42; In Farazmand 2001, Greenwood Press, 23-41.

Chalmers, J., Davis, G. (2001), Rediscovering Implementation: Public Sector Contracting and Human Services, Australian Journal of Public Administration, Vol.60, No.2, 74-85, available at https://onlinelibrary.wiley.com/doi/pdf/10.1111/1467-8500.00212.

Constantinescu, D. (2012), Rolul parteneriatul public-privat în creşterea calităţii serviciilor de asigurare a sănătăţii, Economie teoretică şi aplicată, Volumul XIX(2012), No.10(575), 30-52, available at http://store.ectap.ro/articole/783 ro.pdf.

Donovan, D., Rypkema, Basics of Public-Private Partnerships for Historic Buildings (Heritage PPPs), available at http://www.heritageohio.org/wpcontent/uploads/2013/05/Public-Private-Partnerships-for-HistoricBuildings.pdf.

Friedmann, J., Weaver, C. (1979), Territory and Function: The Evolution of Regional Planning, University of California Press Berkeley and Los Angeles.

Gomes, L. (1990), Neoclassical International Economics: An Historical Survey, Palgrave MacMillan.

Jomo, K.S., Chowdhury, A., Sharma, K., Platz, D. (2016), Public-Private Partnerships and the 2030 Agenda for Sustainable Development: Fit for purpose?, Department of Economic \& Social Affairs, DESA Working Paper, No. 148 ST/ESA/2016/DWP/148, available http://www.un.org/esa/desa/papers/2016/wp148_2016.pdf.

Kwame, S.J., Chowdhury, A. (2009), Reconsidering Public-Private Partnerships in Developing Countries, International Journal of Institutions and Economies, Vol. 1(2), 199-205.

Levai, C.M., Aspecte teoretico-practice privind parteneriatul public-privat în Uniunea Europeană, available at http://www.ugb.ro/Juridica/Issue1RO/11_Parteneriatul_publicprivat_in_UEMihaela_LevaiRO.pdf.

Lewis, M.K. (2001), Risk Management in Public-Private Partnerships. Econstor, available at https://www.econstor.eu/handle/10419/31983.

Marinescu, C., Economia sectorului public, Note de curs, http://www.cse.uaic.ro/_fisiere/Documentare/Suporturi_curs/III_Economia_se ctorului_public.pdf.

McDonald, H. (2001), Don't Worry, Singapore Bids Are Not Quite the Yellow Peril, Sydney Morning Herald. 
McQuaid, R.W., Scherrer, W. (2009), Changing reasons for public private partnerships, Working Paper, Econstor, Working Papers in Economics and Finance, University of Salzburg, No. 2009-02, 27-34, available at https://ideas.repec.org/p/ris/sbgwpe/2009_002.html.

McQuaid, R.W. (2000), The theory of partnership: Why have partnerships?, January, in S. P. Osborne (ed.), Managing public-private partnerships for public services: an international perspective (Routledge, London), 9-35, available at https://www.researchgate.net/publication/291300642 The theory of partners hip_Why have partnerships.

McQuaid, R.W. (2000), 1. The theory of partnership: Why have partnerships?, January, in Part I Understanding public-private partnerships in Osborne S. P. (ed.), Public Private Partnership. Theory and Practice in International Perspective, Edited by Stephen P. Osborne, Routledge Taylor \& Francis Group e-Library.

Muetzelfeldt, M. (2001), The Facilitative State and the Symbolic Potency of Mutual Obligation, Australian Journal of Public Administration, Vol. 60 (2), 99-110.

Nioche, J.P. (1991), Management public: à la recherche de nouvelles régulations, Revue Française de Gestion, No. 85, 50-53.

Nuallain, C.O., Wettenhall, R.L. (1987), Public Enterprise: The Management Challenge, International Institute of Administrative Sciences.

Osborne, P.S. (2000, 2005), Public Private Partnership. Theory and Practice in International Perspective, Edited by Stephen P. Osborne, Routledge Taylor \& Francis Group e-Library.

Osborne, P.S. (ed.) (2000), Managing public-private partnerships for public services: an international perspective, (Routledge, London).

Osborne, D., Gaebler, T. (1992), Reinventing Government: How the Entrepreneurial Spirit is Transforming the Public Sector, The Academy of Management Review, 1976-2011, Vol. 1, No. 1 - Vol. 36, No. 4.

Pongsiri, N. (2002), Regulation and public-private partnerships, The International Journal of Public Sector Management, Vol. 15, No. 6, 487-495.

Reneaud, C. (2007), Les partenariats public-privé: un héritage positif pour les générations futures? Mémoire pour le Master professionnel : Management du secteur public: collectivités et partenaires, available at http://doc.sciencespolyon.fr/Ressources/Documents/Etudiants/Memoires/Cyberdocs/Masters/MSPC P/reneaud_c/pdf/reneaud_c.pdf.

Rodriguez, J. (2016), Public Private Partnership Pros and Cons, Public Private Partnership (P3) Benefits and Disadvantages, available at https://www.thebalance.com/public-private-partnership-pros-and-cons-844713.

Savas, E.S. (1982), Privatizing the Public Sector: How to Shrink Government, (Chatham House series on change in American politics), Chatham, Chatham House Publishers.

Savas, E.S. (2000), Privatisation and Public-Private Partnerships, New York, Chatham House Publishers.

Schümperli, Y.C., Dommen, E. (2005), Les partenariats public-privé, enjeux et défis pour la coopération au développement Partenariats public-privé et coopération internationale, Annuaire Suisse de politique de développement, 24-2, 9-19, available at https://aspd.revues.org/335; http://journals.openedition.org/aspd/335.

Tang, K.L. (1997), Efficience du secteur privé dans les services publics : une analyse critique, Revue Internationale des Sciences Administratives, Vol. 63, No. 4, 539-556. 
Thynne, I. Ariff, M. (1987), Singapore Airlines: A Study in the Management of Privatization. In Colm $\mathrm{O}$ Nuallain and Roger Wettenhall (eds.), Public Enterprise: The Management Challenge. Brussels: International Institute of Administrative Sciences, 111-129.

Van Herpen GWEB (2002), Public Private Partnerships, the Advantages and Disadvantages Examined, European Transport Conference, availabke at www.abstracts.aetransport.org/paper/download/id/1466.

Weidenbaum, M.L. (1969), The Modern Public Sector: New Ways of Doing the Government's Business. New York, Basic Books.

Wettenhall, R. (2003), The Rhetoric and Reality of Public-Private Partnerships, Public Organization Review: A Global Journal, Vol. 3 Issue 1, 77-107, Kluwer Academic Publishers. Manufactured in The Netherlands.

Government Accounting Office (1999), Public-Private Partnerships: Terms Related to Building and Facility Partnerships, available at https://www.gao.gov/special.pubs/Gg99071.pdf.

Toolkit for Public-Private Partnerships in Road \& Highways, Overview of PPP experience, PPIAF, Module 1: Overview and Diagnosis March 2009, available at

https://ppiaf.org/sites/ppiaf.org/files/documents/toolkits/highwaystoolkit/6/pdfversion/1-21.pdf.

Toolkit for Public-Private Partnerships in Roads \& Highways, PPIAF, Main types of PPP, Module 1: Overview and Diagnosis March 2009 available at https://ppiaf.org/ppiaf/sites/ppiaf.org/files/documents/toolkits/highwaystoolkit/ 6/pdf-version/1-13.pdf.

Toolkit for Public-Private Partnerships in Roads \& Highways, PPIAF, Institutional framework, Module 4: Laws and contracts March 2009, available at https://ppiaf.org/sites/ppiaf.org/files/documents/toolkits/highwaystoolkit/6/pdfversion/4-21.pdf.

OECD (2008), Public-Private Partnerships: In Pursuit of Risk Sharing and Value for Money, June, OECD, Paris.

United Nations Economic Commission for Europe (UNECE) (2008), Guidebook on Promoting Good Governance in Public-Private Partnerships, January, United Nations, New York and Geneva, available at https://www.unece.org/fileadmin/DAM/ceci/publications/ppp.pdf.

World Bank Group, PPIAF (2016), The State of PPPs Infrastructure Public-Private Partnerships in Emerging Markets \& Developing Economies 1991-2015, June, available at https://ppiaf.org/documents/3551/download/.

World Bank Group, PPPIRC - Public-Private Partnership in Infrastructure Research Center, Toolkit for Public-Private Partnerships in Roads and Highways, available at https://ppp.worldbank.org/public-privatepartnership/library/toolkit-public-private-partnerships-roads-and-highways.

World Bank, PPPIRC - Public Public-Private-Partnership In Infrastructure Resource Center, PPP Arrangement/Types of Public Private-Partnerships Agreements, 2016-07-13, available at https://ppp.worldbank.org/public-privatepartnership/agreements.

World Bank Group, PPPIRC - Public-Private-Partnership in Infrastructure Resource Center, Main Financing Mechanism, for Infrastructure Projects, PPPIRC 201609-06,

https://ppp.worldbank.org/public-privatepartnership/financing/mechanisms\#corporate. 
World Bank Group, PPIRC - Public-Private-Partnership in Infrastructure Resource Center Government Objectives, Benefits and Risks of PPPs, 2016-10-31, available at https://ppp.worldbank.org/public-privatepartnership/overview/ppp-objectives.

The National Council for Public-Private Partnership, Types of Partnerships, extracted from Public-Private Partnerships: Terms Related to Building and Facility Partnerships, Government Accounting Office, April 1999, available at http://www.ncppp.org/ppp-basics/types-of-partnerships/.

International Monetary Found - IMF (2004), Public-Private Partnerships, Fiscal Affairs Department, (In consultation with other departments, the World Bank, and the Inter-American Development Bank), March 12, Approved by Teresa Ter-Minassian available at http://www.imf.org/external/np/fad/2004/pifp/eng/031204.pdf.

Ce este Parteneriatul Public - Privat, România-Ucraina-Republic Moldova Program de Cooperare Transfrontalieră, Mediul de afaceri - Promovare şi dezvoltare sustenabilă (MIS-ETC 2458) Programul Operaţional Comun RomâniaUcraina-Republica Moldova 2007-2013, available at http://www.agrofoodlowdanube.ro/ro/academia-de-business/22-ce-este-parteneriatul-publicprivat.html.

Rui, C.M. (2010), What are the different types of PPP arrangements? Response by Rui Cunha Marques, February, 2010, Frequently Asked Questions -> PrivatePublic Partnerships: Contracts and Risks, Body of Knowledge on Infrastructure Regulation, available at http://regulationbodyofknowledge.org/faq/private-public-partnershipscontracts-and-risks/what-are-the-different-types-of-ppp-arrangements/.

Legea 233/2016 privind parteneriatul public-privat, MO Partea I nr. 954 din 25 noiembrie 2016, available at http://www.dreptonline.ro/legislatie/legea_233_2016_parteneriatul_public_pri vat.php.

Legea parteneriatului public-privat nr. 178/2010, MO Partea I nr. 676 din 5 octombrie 2010, available at http://dpiis.gov.ro/new dpiis/wpcontent/uploads/2014/05/LEGE-nr-178-din-2010-actualizata-in-data-de23.04.2013.pdf. 